\title{
Forming health culture as part of general education
}

\author{
Irina Andreeva ${ }^{1, *}$ \\ ${ }^{1}$ ISED RAE, Center for Science Education, 105062, Moscow, Russia
}

\begin{abstract}
The paper outlines methods of forming health culture in the content of education as a theoretical-methodological area aimed at fostering a positive attitude, sustained motivation for health and personal responsibility for its preservation.
\end{abstract}

\section{Introduction.}

Maintaining the health of the nation on the basis of health culture as a component of general human culture is aimed at increasing human capital, enhancing socioeconomic growth and social security of a nation $[1,2]$.

The formation of a healthy individual on the basis of the culture of a healthy and safe lifestyle through the medium of education content is determined by Educational Standards [3].

The purport of this study is to define the concept of "health culture" in the content of education and outline methods of its formation with the aim of bringing up a healthy individual.

\section{What is "health culture".}

In the context of the general human culture, the concept of "health culture" is seen as a multidimensional entity reflecting a harmonious and integral individual effectively interacting with the surrounding world, capable of creative self-expression and active life activity.

In the content of education in the framework of cultural studies as a concrete scientific methodology of cognition, the concept of "health" is intimately connected with the concepts of Man and culture (Man being its creator and exponent). These concepts interact through the transfer of experience as the vehicle of cultural values in the framework of pedagogically adapted scientific knowledge (philosophy, medicine, biology, history, sociology, cultural studies, psychology, etc.) and activities aimed at promoting moral, physical and intellectual harmony of the individual.

Health culture is an integral pedagogical area of knowledge which sets and solves theoretical and practical tasks of harmonious development of human spiritual, mental and physical abilities drawing on the experience of activity, ensuring socialization and social success through educational content.
Health culture is social experience that ensures socialization, social success and survival of Man as a species. It is not confined to the information component on health and a healthy way of life, which cannot provide the basis for an inner attitude, needs and desire to act and create a motivation for health. The process of inculcating health culture is based on education, development and instruction. An individual's health culture is a frame of mind, value orientations and attitudes, a certain level and style of life, an abiding intellectual and emotional need formed in the process of systematic, purposeful instruction and upbringing on the basis of an emotional-value-related attitude to health through accumulation of experience of knowledge, its application, and the development of habits in the practice of organizing a healthy life style.

The process of formation of health culture is based on the psycho-physiological features of its development $[4,5]$. The best period for such development is arguably the period of school education when the most socially important factor is the age of adolescence. Accordingly, the formation of a health culture should predominate in the framework of basic general education as a model of behavior that underpins successful development of a healthy individual.

\section{Forming health culture during education.}

In the context of the new Educational Standard of Basic General Education the formation of health culture is a mandatory part of education content [6]. Health culture is inculcated through imparting the necessary knowledge about health and corresponding skills as part of implementing educational standards.

The formation of health culture involves the achievement of personal and concrete results on the basis of assimilation of universal educational actions. Of particular importance is the achievement of results in the teaching of natural sciences that provides the student with a modern natural science picture of the

Corresponding author: andreevaira1@yandex.ru 
world which forms the context of a scientific concept of health and a healthy life style [7].

In the context of natural science education health culture is formed in the process of acquiring knowledge in the fields of biology, chemistry and physics on the basis of integration of these subjects into a single scientific basis of understanding health issues (physiological knowledge of the human being as a biological species is based on physical-chemical processes taking place in the organism). Interdisciplinary links is the precondition for incorporating the system of health knowledge in the content of education which makes it possible, without blurring the boundaries between different subjects, to study the issues of health highlighting the key elements of the discipline connected with health, to promote system-forming and health-preserving ideas, concepts and the possibilities of comprehensive application of knowledge in real life. The key element in introducing the values of health in the content of education is the section of the Biology course called "The Human Being and His/Her Health" which equips the student with understanding of the processes taking place in the human organism [8]. Pedagogically adapted scientific knowledge (medical, sanitary-hygienic, physical culture and health activities) and practical skills form the basis of health culture. The inclusion of pedagogically adapted educational information on health in the content of various subjects presupposes the development of an awareness of health issues and their study in close connection with the practical life phenomena with due account of the contemporary challenges of social development. The study of health issues in the course of school education should be seen in the context of the development of new information technologies (problems of psychosomatic health under the impact of information technologies); sociodemographic indicators (birth rate, mortality, life expectancy, migration); the processes of democratization of society (inter-cultural adaptation, tolerance); breakthroughs in the field of biology, medicine (development of biotechnologies, the discovery of genetic engineering, transplantology, space and Arctic medicine); ecological-biological features of contemporary environment (the impact of the radiation background, temperature anomalies, ultraviolet radiation, human-induced catastrophes, natural disasters); socio-cultural practices, risks and society's vulnerabilities (food and survival of the human species, modern vegetable and animal food products); profiles of psycho-physiological and somatic health of the young generation (features of physical development - retardation, deceleration); the modern pace of life (stresses and adaptation capacity of children and adolescents); and modern epidemics and pandemics (tuberculosis, Ebola virus, AIDS and the social problems of people infected with HIV) [9].

The above-mentioned problems should be represented in the content of education as a pedagogically adapted system of knowledge on health on the basis of culture-oriented, social and anthropological approaches $[2,3]$. The mechanism that is called upon to form the culture of health in the content of education is teaching activities based on modern teaching methods in the framework of practical and cognitive instructional tasks that include the issues of health and the healthy life style.

The aim of forming a health culture in the content of general education is achievement of individual results on the basis of practical activities. The key criterion of personal achievement in the process of health instruction is the level of natural science literacy which ensures correct decisions and fosters an engaged attitude to health matters leading to the maintenance of health.

\section{Conclusion.}

Health culture in the content of education is a new theoretical-methodological area which has essential practical implications for solving educational and character-molding tasks in bringing up a healthy individual through the content of general education on the basis of modernization of the content of education on health matters: analysis and identification of potential of study subjects, development of interdisciplinary links, account of modern scientific achievements and present-day psycho-physiological characteristics of students.

\section{References}

1. I.G. Andreeva, Pedagogika 10 (2012) [In Rus]

2. I.G. Andreeva, Standarty i monitoring v obrazovanii 3 (2011) [In Rus]

3. I.G. Andreeva, Pedagogika 10 (2011) [In Rus]

4. I.G. Andreeva, Pedagogika 2, (2003) [In Rus]

5. I.G. Andreeva, Physiological Mechanisms of the Generation of Distonic States: monograph. (Intellect Tsentr, Moscow, 2006) [In Rus]

6. I.G. Andreeva, Fizika v shkole 7 (2013) [In Rus]

7. I.G. Andreeva, Pedagogika 8 (2015) [In Rus]

8. I.G. Andreeva, Pedagogika 5 (2012) [In Rus]

9. I.G. Andreeva, Pedagogika 8 (2014) [In Rus] 